\title{
The role of leptin in the regulation of TSH secretion in the fed state: in vivo and in vitro studies
}

\author{
T M Ortiga-Carvalho, K J Oliveira, B A Soares \\ and C C Pazos-Moura
}

Laboratório de Endocrinologia Molecular, Instituto de Biofísica Carlos Chagas Filho, Universidade Federal do Rio de Janeiro, Universidade do Brasil,
CCS-Cidade Universitária, Ilha do Fundão, Rio de Janeiro, Brazil
(Requests for offprints should be addressed to C C Pazos-Moura; Email: cpazosm@biof.ufrj.br)

\begin{abstract}
Leptin has been shown to stimulate the hypothalamuspituitary-thyroid axis in fasting rodents; however, its role in thyroid axis regulation under physiological conditions is still under investigation. Here it was investigated in freely fed rats whether leptin modulates thyrotroph function in vivo and whether leptin has direct pituitary effects on TSH release. Since leptin is produced in the pituitary, the possibility was also investigated that leptin may be a local regulator of TSH release. TSH was measured by specific RIA. Freely fed adult rats $2 \mathrm{~h}$ after being injected with a single s.c. injection of $8 \mu \mathrm{g}$ leptin $/ 100 \mathrm{~g}$ body weight showed a 2 -fold increase in serum TSH $(P<0 \cdot 05)$. Hemi-pituitary explants incubated with $10^{-9}$ and $10^{-7} \mathrm{M}$
\end{abstract}

leptin for $2 \mathrm{~h}$ showed a reduced TSH release of 40 and $50 \%$ respectively $(P<0 \cdot 05)$. Conversely, incubation of hemi-pituitary explants with antiserum against leptin, aiming to block the action of locally produced leptin, resulted in higher TSH release $(45 \%, P<0 \cdot 05)$. In conclusion, also in the fed state, leptin has an acute stimulatory effect on TSH release in vivo, acting probably at the hypothalamus. However, the direct pituitary effect of leptin is inhibitory and data also provide evidence that in the rat pituitary leptin may act as an autocrine/paracrine inhibitor of TSH release.

Journal of Endocrinology (2002) 174, 121-125

\section{Introduction}

Leptin, a satiety factor produced mainly in the adipose tissue, is also involved in the neuroendocrine regulation of pituitary function (Ahima et al. 2000). Most studies concerning leptin action on the thyroid axis focus on the fasting situation and favour the concept that leptin acts primarily on the hypothalamus, stimulating directly or indirectly thyrotrophin-releasing hormone (TRH) production and release (Legradi et al. 1997, Kim et al. 2000, Nillni et al. 2000, Harris et al. 2001). In fasting rats, the administration of leptin partially prevents the fall in serum thyroid hormones and thyrotrophin (TSH) induced by fasting (Ahima et al. 1996, Seoane et al. 2000). Although there are convincing reports implicating leptin depletion in the suppression of the pituitary-thyroid axis during starvation, the role of leptin in the maintenance of this axis under physiological conditions is unclear. In humans, leptin or leptin receptor deficiency is very rare and, in a few cases, seem to lead to mild central hypothyroidism in children, but not in adults (Montague et al. 1997, Clement et al. 1998, Ozata et al. 1999). In addiction, depression of the hypothalamus-pituitary-thyroid axis has not been clearly demonstrated in leptin- or leptin receptor-deficient rodents. There are some reports suggesting that in the early life of obese mice (ob/ob) was presented a mild hypothyroid phenotype (Mobley \& Dubuc 1979); however, in adulthood, serum TSH, thyroxine $\left(\mathrm{T}_{4}\right)$ and triiodothyronine $\left(T_{3}\right)$ levels are normal (Dubuc 1991) or even slightly higher (Mobley \& Dubuc 1979).

The detection of leptin receptor in the human (Jim et al. 1999, Knerr et al. 2001, Korbonits et al. 2001) and rat (Jim et al. 2000, Sone et al. 2001) pituitary gland raises the possibility that circulating leptin might also act directly to modulate TSH release. It has been shown that leptin regulates secretion of other pituitary hormones from isolated glands or cell cultures (Casanueva \& Dieguez 1999). It is not known whether TSH release is modulated by a direct pituitary action.

Moreover, recently, leptin was also found in human (Jim et al. 1999), rat and mouse (Jim et al. 2000, Sone et al. 2001) anterior pituitary gland. The local synthesis of leptin is supported by the presence of leptin mRNA, in rat and mouse pituitaries, and in human pituitary adenomas (Morash et al. 1999, Jim et al. 2000, Knerr et al. 2001, Korbonits et al. 2001). Additionally, in rat and mouse pituitaries, thyrotrophs and other pituitary cells express leptin and leptin receptors (Morash et al. 1999, Jim et al. 
2000, Korbonits et al. 2001, Knerr et al. 2001). Altogether, the data raise the hypothesis of a local role of leptin as an autocrine/paracrine regulator of TSH release.

Therefore, here we have addressed the questions of whether leptin is able to modulate thyrotroph function in the fed state, whether leptin acts directly at the pituitary and, also, we have investigated the hypothesis that pituitary leptin may be an autocrine/paracrine TSH regulator in the rat pituitary.

\section{Materials and Methods}

Animals

Adult male Wistar rats, weighing 250-300 g, were kept under controlled lighting (12 h light:12 h darkness cycle, lights on at $0600 \mathrm{~h})$ and controlled temperature $(23 \pm$ $1{ }^{\circ} \mathrm{C}$ ). All experimental protocols were approved by our institutional animal care committee (CAUAP).

\section{In vivo experiments}

The rats were divided into three groups that received a single s.c. injection of 8 or $16 \mu \mathrm{g} / 100 \mathrm{~g}$ body weight (BW) mouse recombinant leptin (NPHP, NIH, Torrance, CA, USA) or $0.2 \mathrm{ml}$ saline vehicle (control group). The rats were killed by decapitation, $30 \mathrm{~min}$ or $120 \mathrm{~min}$ after the injection. Serum was obtained from the trunk blood to measure TSH.

\section{In vitro experiments}

Animals were killed by decapitation, and their anterior pituitaries were quickly dissected out. Each hemi-pituitary was immediately transferred to one flask containing $1 \mathrm{ml}$ Krebs-Ringer bicarbonate medium $(\mathrm{pH} 7 \cdot 4)$ at $37^{\circ} \mathrm{C}$ in an atmosphere of $95 \% \mathrm{O}_{2} / 5 \% \mathrm{CO}_{2}$ in a Dubnoff metabolic shaker. After a $30 \mathrm{~min}$ preincubation period, medium was changed to $1 \mathrm{ml}$ medium alone (control) or medium containing mouse recombinant leptin to a final concentration of $10^{-11}, 10^{-9}$ or $10^{-7} \mathrm{M}$. At the end of a $2 \mathrm{~h}$ incubation an aliquot was removed for $\mathrm{TSH}$ measurement.

In another experiment, using the same in vitro system, hemi-pituitaries were incubated in the presence of antiserum against leptin (rabbit anti-mouse leptin; NHPP, $\mathrm{NIH})$ at 1:2000 or 1:500 dilutions. Control hemipituitaries were incubated with normal rabbit serum (NRS) at 1:500 dilutions. After $1 \mathrm{~h}$, an aliquot of medium was removed to measure TSH and the incubation was allowed to continue for another $1 \mathrm{~h}$. After incubation, another aliquot was obtained for TSH quantification.

\section{Quantification of TSH}

TSH concentration in the serum and in the incubation medium was measured by specific RIA, employing

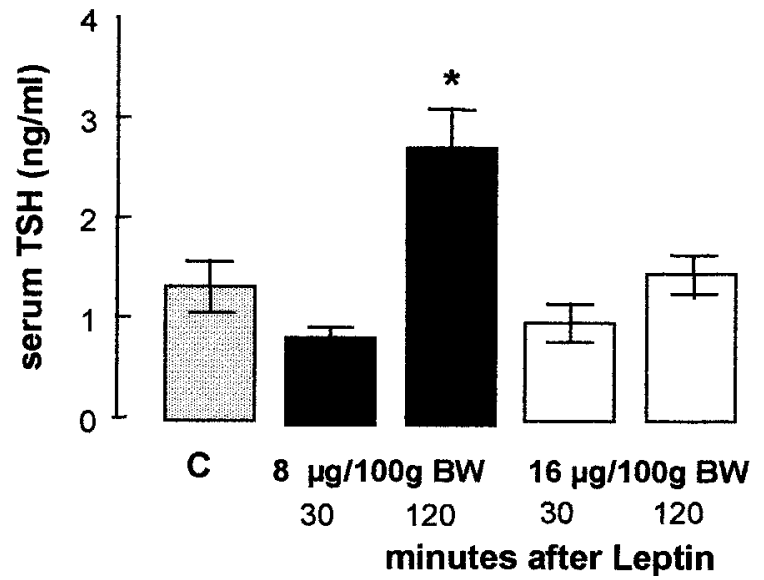

Figure 1 Effect of a single injection of leptin (8 or $16 \mu \mathrm{g} / 100 \mathrm{~g}$ BW) after 30 min and $2 \mathrm{~h}$ on serum TSH. $n=8-12$ animals. Data represent means \pm S.E.M. ${ }^{*} P<0.05$ vs $C$ (control vehicle-injected).

reagents supplied by the National Institute of Diabetes, Digestive and Kidney Diseases (NIDDK) (Torrance, CA, USA), as previously described (Chard 1987, OrtigaCarvalho et al. 1996), and was expressed in terms of the reference preparation (RP3). Within-assay variation was $7 \cdot 9 \%$, and the coefficient of variation between assays was $6.7 \%$. Minimum assay detection was $0.52 \mathrm{ng} / \mathrm{ml}$.

\section{Statistical analysis}

Data are reported as means \pm S.E.M. One-way ANOVA followed by a Student-Newman-Keuls multiple comparisons test was employed for assessment of significance of all data except for serum TSH, which was analysed by ANOVA only after logarithmic transformation (Zar 1996). Differences were considered to be significant at $P<0 \cdot 05$.

\section{Results}

In vivo experiments

The administration of $8 \mu \mathrm{g} / 100 \mathrm{~g}$ BW of mouse recombinant leptin to rats induced, after $2 \mathrm{~h}$, a 2 -fold increase in serum TSH when compared with control group values $(P<0 \cdot 05$, Fig. 1). No significant effect was observed earlier, at $30 \mathrm{~min}$. The higher dose of leptin $(16 \mu \mathrm{g} / 100 \mathrm{~g}$ $\mathrm{BW}$ ) was not able to significantly change serum TSH.

\section{In vitro experiments}

Leptin-incubated hemi-pituitary glands showed a dosedependent decrease in TSH release, statistically significant at $10^{-9} \mathrm{M}$ and $10^{-7} \mathrm{M}(P<0 \cdot 05)$, with a reduction of 40 and $50 \%$ respectively (Fig. 2 ).

The presence of antiserum against leptin at 1:500 dilution for $2 \mathrm{~h}$ in incubation media of hemi-pituitaries 


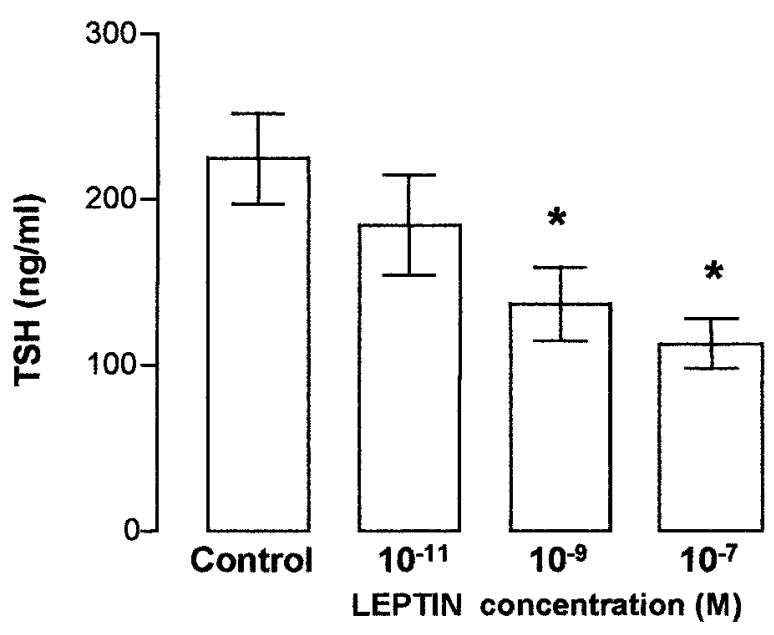

Figure $2 \mathrm{TSH}$ release from isolated rat hemi-pituitary glands incubated in absence (Control) or presence of mouse recombinant leptin at different concentrations for 2 h. $n=14-18$ hemipituitaries. Data represent means \pm S.E.M. ${ }^{*} P<0 \cdot 05$ vs control.

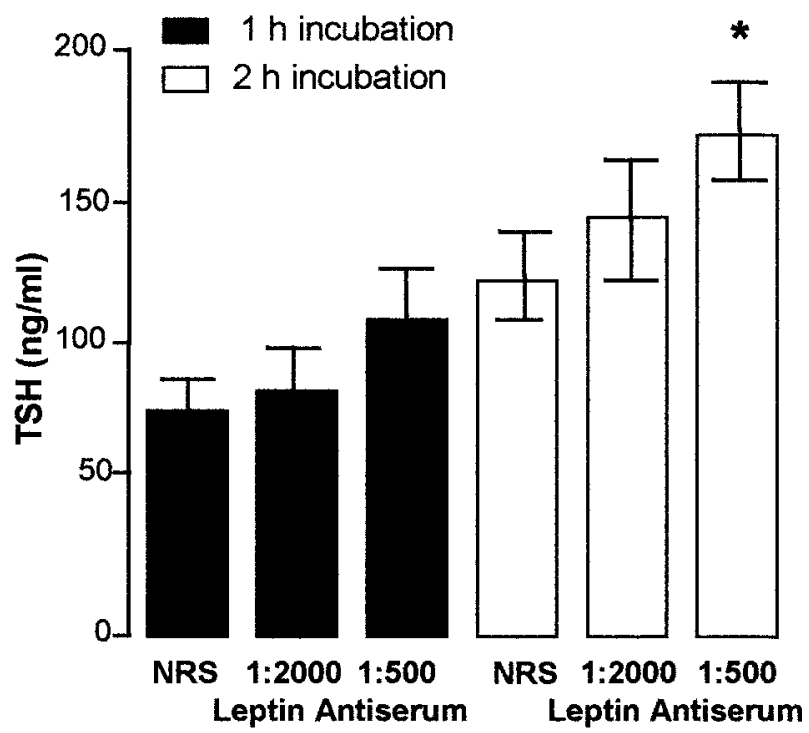

Figure 3 TSH release from isolated rat hemi-pituitary glands after 1 or $2 \mathrm{~h}$ incubation in the presence of antiserum against mouse leptin at 1:200 and 1:500 dilution or NRS at 1:500 dilution. $n=12-14$ hemi-pituitaries. Data represent means \pm S.E.M. ${ }^{*} P<0 \cdot 05$ vs NRS at $2 \mathrm{~h}$.

resulted in an approximately $40 \%$ increase in TSH release $(P<0 \cdot 05)$ as compared with NRS-incubated hemipituitaries incubated for $2 \mathrm{~h}$ at 1:500 dilution. The highest dilution of the antiserum $(1: 2000)$ had no statistically significant effect, although the mean TSH secretion was elevated by approximately $20 \%$ (Fig. 3). At $1 \mathrm{~h}$ incubation, the antiserum caused no statistically significant changes, even though a trend to a rise in TSH release was observed in glands incubated with the smallest dilution (1:500) of the leptin antiserum (Fig. 3).

\section{Discussion}

Here we first demonstrated that systemically administered leptin, in an appropriately low dose, has an acute stimulatory effect on TSH secretion in fed rats, as had been observed in fasting rodents by others (Ahima et al. 1996, Seoane et al. 2000). This effect is independent of leptininduced changes in food intake, since observations were made very shortly after leptin administration $(2 \mathrm{~h})$. Therefore, leptin has direct excitatory effects on the hypothalamic-pituitary-thyroid axis in the fed state. Although it is a moderate effect, the results favour a role for leptin in the modulation of the thyroid axis in physiological conditions.

The leptin stimulatory effect on TSH secretion, observed in vivo, is not due to a direct pituitary action, since isolated hemi-pituitaries respond to leptin by decreasing TSH release. Although it is a moderate effect, it is clearly demonstrated at concentrations in a physiological range. Moreover, the increment in TSH release from isolated hemi-pituitaries by immunoneutralization of endogenous pituitary-produced leptin is highly suggestive that leptin acts as an autocrine/paracrine inhibitor of TSH secretion. This possibility is further reinforced by the previous demonstration of the presence of leptin and leptin receptors in rodent thyrotrophs (Jim et al. 2000, Sone et al. 2001). In vivo and in vitro opposite effects on TSH secretion have been shown for other neuropeptides, such as galanin (Ottlecz et al. 1988) and substance $\mathrm{P}$ (Mitsuma \& Nogimori 1984, Moura et al. 1999).

Korbonits et al. (2001) had shown that leptin induced an increase in TSH release from a somatotroph adenoma in culture. This opposite response to leptin compared with our study may be related to species differences, to the fact that it is an abnormal human tissue or even to the longer time of incubation with leptin $(24 \mathrm{~h})$. Nevertheless, the study of Korbonits et al. (2001) further supports the role of pituitary leptin as a local regulator of TSH release.

Our results also seem to indicate that at least acutely, after a rapid increase in the circulation, the leptin stimulatory hypothalamic action on TRH neurons (Nillni et al. 2000, Harris et al. 2001) overrides the direct pituitary inhibitory effect on TSH release. This would argue in favour of the predominance of the hypothalamic effect over the pituitary one. Although it seems true for an acute administration and also in the fasting situation, it would not explain the absence of abnormalities on hormone secretion in adult obese leptin-deficient humans and mice (ob/ob). In ob/ob mice serum TSH, $\mathrm{T}_{4}$ and $\mathrm{T}_{3}$ are reported to be normal (Mobley \& Dubach 1979, Dubach 1991) or even slightly higher (Mobley \& Dubach 1979). Although there are differences between rodents and humans that are deficient in leptin or leptin receptor, also in humans only children have been reported to have mild central hypothyroidism and the affected adults seem to have a normal thyroid axis (Montague et al. 1997, Clement 
et al. 1998, Ozata et al. 1999). However, more studies are necessary to clarify the question of leptin deficiency and its consequences for the thyroid axis in humans.

In addition, a stimulatory effect on serum TSH could not be demonstrated by chronic treatment of fed rats with leptin (Cusin et al. 2000, Nowak et al. 2002). Leptintreated animals, however, showed higher serum $\mathrm{T}_{3}$ than a saline-injected pair-fed group in association with an increase in liver $5^{\prime}$-deiodinase activity. It is possible that a stimulatory effect on deiodinase, increasing serum $\mathrm{T}_{3}$ feedback at the hypothalamus and the direct inhibitory effect of leptin on the thyrotroph demonstrated in the present study, are counteracting the stimulatory hypothalamic action of leptin. Therefore, leptin seems to have several targets on the thyroid axis, and the physiological effect of leptin may be the result of its various effects on those targets.

The fact that the highest dose of leptin did not change significantly the thyrotroph parameters studied may be consequent to secondary actions of leptin induced by the high but not the low dose. The same dose relationship was observed by other authors studying the adrenal-pituitary axis (Malendowicz et al. 1998), and therefore it is possible that this may be a more general feature of dose-related effects of leptin.

In conclusion, here we first demonstrated that leptin has an in vivo acute stimulatory effect on TSH release in freely fed rats, as others had demonstrated in fasting rats. However, our data demonstrated that the direct action of leptin at the rat pituitary is to inhibit TSH release and, moreover, the present study also showed evidence of a role for locally produced leptin as an autocrine/paracrine inhibitor of TSH release. Overall, the results lead to the suggestion that the physiological role of leptin on TSH release, at least in rats, may be the result of a stimulatory effect at the hypothalamus and inhibitory at the pituitary.

\section{Acknowledgements}

The authors thank Dr A Parlow, National Pituitary Program (NIDDK) for kindly providing us with the recombinant mouse leptin and antiserum against leptin. This research was supported by CNPq, CEPG/UFRJ, and FAPERJ.

\section{References}

Ahima RS, Prabakaran D, Mantzoros C, Qu D, Lowell B, Maratos-Filer E \& Flier JS 1996 Role of leptin in the neuroendocrine response to fasting. Nature 382 250-252.

Ahima RS, Saper CB, Flyer JS \& Elmquist JK 2000 Leptin regulation of neuroendocrine systems. Frontiers in Neuroendocrinology 21 263-307.

Casanueva F \& Dieguez C 1999 Neuroendocrine regulation and actions of leptin. Frontiers in Neuroendocrinology 20 317-363.
Chard T 1987 An introduction to radioimmunoassay and related techniques. In Laboratory Techniques in Biochemistry and Molecular Biology, pp 1-74. Eds RH Burdon \& PH van Kiniooenberg. Amsterdam: Elsevier Science.

Clement K, Vaisse C, Lahlou N, Cabrol S, Pelloux V, Cassuto D, Gourmelen M, Dina C, Chambaz J, Lacorte JM, Basdevant A, Bougneres P, Lebouc Y, Froguel P \& Guy-Grand B 1998 A mutation in the human leptin receptor gene causes obesity and pituitary dysfunction. Nature 392 398-401.

Cusin I, Rouru J, Visser T, Burger AG \& Rohner-Jeanrenaud F 2000 Involvement of thyroid hormones in the effect of intracerebroventricular leptin infusion on uncoupling protein-3 expression in rat muscle. Diabetes 49 1101-1105.

Dubuc PU 1991 Effects of phenotype, feeding condition and cold exposure on thyrotropin and thyroid hormones of obese and lean mice. Endocrine Regulation 25 171-175.

Harris M, Aschkenasi C, Elias CF, Chandrankunnel A, Nillni EA, Bjoorbaek C, Elmquist JK, Flier JS \& Hollenberg AN 2001 Transcriptional regulation of the thyrotropin-releasing hormone gene by leptin and melanocortin signaling. Journal of Clinical Investigation 107 111-120.

Jim L, Burguera BG, Couce ME, Scheithauer BW, Lamson J, Eberhardt NL, Kulig E \& Lloyd RV 1999 Leptin and leptin receptor expression in the normal and neoplastic human pituitary: evidence of a regulatory role of leptin on pituitary cell proliferation. Journal of Clinical Endocrinology and Metabolism 84 2903-2911.

Jim L, Zhang S, Burguera BG, Couce ME, Osamura RY, Kulig E \& Lloyd RV 2000 Leptin and leptin receptor expression in rat and mouse pituitary cells. Endocrinology 141 333-339.

Kim MS, Small CJ, Stanley SA, Morgan DG, Seal LJ, Komg WM, Edwards CM, Abusnana S, Sunter D, Ghatei MA \& Bloom SR 2000 The central melanocortin system affects the hypothalamicpituitary-thyroid axis and may mediate the effect of leptin. Journal of Clinical Investigation 105 1005-1011.

Knerr I, Schuster S, Nomikos P, Buchfelder M, Dotsch J, Schoof E, Fahlbusch R \& Rascher W 2001 Gene expression of adrenomedullin, leptin, their receptors and neuropeptide $\mathrm{Y}$ in hormone-secreting and non-functioning pituitary adenomas, meningiomas and malignant intracranial tumors in humans. Neuropathology and Applied Neurobiology 3 215-222.

Korbonits M, Chitnis MM, Gueorguiev M, Norman D, Rosenfelder N, Suliman M, Jones H, Noonan K, Fabbri A, Besser GM, Burrin JM \& Grossman AB 2001 The release of leptin and its effect on hormone release from human pituitary adenomas. Journal of Clinical Endocrinology $\mathbf{5 4}$ 781-789.

Legradi G, Emerson CH, Ahima RS, Flier JS \& Lechan RM 1997 Leptin prevents fasting-induced suppression of prothyrotropinreleasing hormone messenger ribonucleic acid in neurons of the hypothalamic paraventricular nucleus. Endocrinology 138 2569-2576.

Malendowicz LK, Macchi C, Nussdorfer GG \& Nowak KW 1998 Acute effects of recombinant murine leptin on rat pituitaryadrenocortical function. Endocrine Research 24 235-246.

Mitsuma T \& Nogimori T 1984 Effects of substance P, angiotensin II, oxotremorine and prostaglandin $\mathrm{D}_{2}$ on thyrotropin secretion in rats. Hormone Research 19 176-184.

Mobley PW \& Dubuc PU 1979 Thyroid hormone levels in the developing obese-hyperglycemic syndrome. Hormone Metabolism Research 11 37-39.

Montague CT, Farooqi SI, Whitehead JP, Jonathan P, Soos MA, Rau H, Wareham NJ, Sewter CP, Ciaran P, Digby JE, Mohammed SN, Hurst JA, Cheetham CH, Earley AR, Barnett AH, Prins JB \& O'Rahilly S 1997 Congenital leptin deficiency is associated with severe early-onset obesity in humans. Nature 387 903-908.

Morash B, Li A, Murphy RP, Wilkinson M \& Ur E 1999 Leptin gene expression in the brain and pituitary gland. Endocrinology 140 $5595-5998$ 
Moura EG, Santos CV, Santos RMM \& Pazos-Moura CC 1999 Interaction between substance $\mathrm{P}$ and gastrin-releasing peptide on thyrotropin secretion by rat pituitary in vitro. Brazilian Journal of Medical and Biological Research 32 1155-1160.

Nillni EA, Vaslet C, Harris M, Hollenberg A, Bjorbaek C \& Flier JS 2000 Leptin regulates prothyrotropin-releasing hormone biosynthesis. Evidence for direct and indirect pathways. Journal of Biological Chemistry 275 36124-36133.

Nowak KW, Kaczmarek P, Ziolkwska A, Albertin G, Ginda WJ, Trejter M, Nussdorfer GG \& Malendowicz LK 2002 Rat thyroid gland expresses the long form of leptin receptors, and leptin stimulates the function of the gland in euthyroid non-fasted animals. International Journal of Molecular Medicine 9 31-34.

Ortiga-Carvalho TM, Polak J, McCann S \& Pazos-Moura CC 1996 Effect of thyroid hormones on pituitary neuromedin B and possible interaction between thyroid hormones and neuromedin B on thyrotropin secretion. Regulatory Peptides 67 47-53.

Ottlecz A, Snyder GD \& McCann SM 1988 Regulatory role of galanin in control of hypothalamic-anterior pituitary function. PNAS 85 9861-9865.
Ozata M, Ozdemir CI \& Licinio J 1999 Human leptin deficiency caused by a missense mutation: multiple endocrine defects, decreased sympathetic tone, and immune system dysfunction indicate new targets for leptin and spontaneous correction of leptin-mediated defects. Journal of Clinical Endocrinology and Metabolism 84 3686-3695.

Seoane LM, Carro E, Tovar S, Casanueva FF \& Dieguez C 2000 Regulation of in vivo TSH secretion by leptin. Regulatory Peptides 92 25-29.

Sone M, Nagata H, Takekoshi S \& Osamura RY 2001 Expression and localization of leptin receptor in the normal rat pituitary gland. Cell and Tissue Research 305 351-356.

Zar JH 1996 Data Transformations - Biostatistical Analysis, edn 3, pp 277-279. London: Prentice Hall International.

Received 29 January 2002

Accepted 4 April 2002 